\title{
ПРОБЛЕМА ВИБОРУ ОСОБИСТІСТЮ СПОСОБІВ ПОЛІТИКО-ПРАВОВОГО САМОВИЗНАЧЕННЯ В СИТУАЦІї СОЦІАЛЬНИХ ПОТРЯСІНЬ
}

Статтю присвячено створенню теоретичних засад вивчення та оптимізації тих суб'єктивних стратегій, до яких вдається особистість, вирішуючи завдання політико-правової ідентифікації. Обстоюється думка, що в період соціальних потрясінь, що тривають в Україні, результат соціалізації (зокрема набуття політико-правової ідентичності) залежить не стільки від конкуруючих впливів різних агентів соціалізації, скільки від того, як особистість здійснює вибір між різними варіантами осмислення дійсності. Наголошується, що слід досліджувати суб'єктивні способи здійснення особистістю ідентифікаційних виборів, а не обмежуватися лише вивченням змісту та структури набутих нею ідентичностей. Звертається увага на те, що концепція статусів ідентичності Дж. Марсіа спрямована насамперед на розкриття тих способів, за допомогою яких суб'єкт соціалізації створює смислову основу своїх ідентифікаційних виборів. Показано, що залежно від типу самообмежень особистості, які порушують стабілізацію або змінюваність набутої моделі ідентичності, можна виділити чотири основні стратегії взаємодії суб'єкта вибору із суперечливими варіантами конструювання дійсності: 1) збалансована реалізація інтенцій до самоздійснення і саморозвитку (“досягання ідентичності”); 2) обопільне обмеження цих інтенцій (“запозичена ідентичність”); 3) обмеження переважно інтенції до самоздійснення (“дифузна ідентичність”) або 4) інтенції до саморозвитку (“мораторій ідентичності”). Зроблено висновок, що з погляду опанування криз ідентичності найбільш доцільно залучати суб' єкта соціалізації до таких комунікативних практик, у яких знімаються його смислотворчі самообмеження.

Ключові слова: моделі соціалізації особистості, особистісні самообмеження, самоздійснення, саморозвиток, смислотворча комунікація, способи політико-правового самовизначення, статус ідентичності.

Постановка проблеми. Політико-правова соціалізація являє собою процес засвоєння індивідом політичних цінностей і правових норм, необхідних для адаптації в чинній політичній системі та для вибору законодавчо дозволених форм іiї вдосконалення. На етапі трансформації соціальних, економічних та політичних засад суспільства громадяни мусять змінювати свої усталені ідентичності відповідно до нових реалій життя. Завдання самовизначення в новій системі владнопідвладних відносин є само по собі викликом для особистості, оскільки вона має асимілювати новий досвід у раніше набутій системі цінностей, переконань і патернів поведінки. Складність цього завдання відбивається у феномені масових криз ідентичності, який свідчить про те, що значна 
частина населення країни неспроможна підтримувати стійкість своїх конструкцій дійсності в умовах швидких соціокультурних змін.

Якщо період трансформації суспільства затягується на десятиліття, а мінливість не має ознак упорядкованості та послідовності й оцінюється населенням як “протиправна" (що спостерігається в Україні), то громадяни потрапляють у ситуацію, коли старі моделі ідентичності не працюють, а для створення нових немає об'єктивних підстав (затяжні соціальні потрясіння позбавляють особистість надійних орієнтирів для самовизначення). Додатковим потужним чинником ескалації масових криз політико-правової ідентифікації жителів України став воєнний конфлікт на сході країни, тривання якого не тільки дестабілізує економічне, соціальне та політичне життя суспільства, а й наповнює інформаційний простір “войовничим контентом”. 3 одного боку, це “диверсійні” вливання країни-агресора, що веде інформаційну війну за уми громадян, а $з$ другого - це “контрпропаганда" продержавних агентів соціалізації, які “демонізують" не тільки Росію разом з росіянами, а заодно і всіх інакодумців, що не підтримують “позицію влади”. Якщо додати сюди ще й міжпартійні суперечки, які теж відбиваються в суперечливості пропонованих населенню моделей розуміння та оцінювання політико-правової дійсності, то стає очевидним, що результат такої соціалізації (ідентичність) залежить не стільки від змісту і кількості інформаційних впливів, як від того, яким чином суб'єкт соціалізації долає їхню суперечливість, тобто від вибору особистістю способів політико-правового самовизначення.

Аналіз останніх досліджень $i$ публікаиій. Розгляд проблеми політичного та правового самовизначення особистості показує, що основним об'єктом наукового вивчення $є$ змістові та структурні характеристики тих ідентичностей, що притаманні певним групам і спільнотам громадян (В. О. Васютинський, 2014; В. Г. Воропаєва, 2011; Н. В. Хазратова， 2015; О. В. Грицай， М. В. Ніколко， 2009; І. В. Жадан, 2016; Я. М. Куценко, 2011; О.М.Крилов, 2010; В. Л. Носевич, 2005). Вивчається також вплив набутої ідентичності на те, як громадяни оцінюють та переживають кризові ситуації в суспільному житті; до яких сценаріїв розв'язання політико-правових проблем тяжіють (М. Брюер, К. Пірс, 2005; М. В. Тлостанова, 2010; Л. Д. Хашиєва, 2014; М. Хайт, 2014 та ін.). Розкривається зв'язок специфіки соціальної ідентичності особистості $з$ iї психологічним благополуччям (А. Брук, Дж. Гарсія; Л. А. Найдьонова, 2012; М. Флемінг, 2008; І. Сеттлес, 2004; П. Тгойтц, 2003), вивчаються феномени конфлікту ідентичностей (О. Маланчук, В. І. Сусак, 2015; I. Р. Петрівська, 2017; I. Сеттлес, 2004); стереотипних загроз та самостереотипування (self-stereotyping) (Р. Рідел, А. Макконнелл, С. Бейлок, 2009; С. Сінклер, С. Хардін, Б. Лоурі, 2006).

Проблему впливу ситуації соціальних потрясінь на становлення національної ідентичності сучасних українців активно вивчають 
вітчизняні дослідники (П. П. Горностай, 2015; І. В. Остапенко, 2017; 3. Ф. Сіверс, 2015) [2; 7; 9]. Зокрема, велика увага приділяється аналізу негативних соціально-психологічних проявів порушення процесу особистісної ідентифікації (С. Л. Кравчук, 2016; Ю. А. Семенова, 2004; 3. В. Шевченко, 2007) $[5 ; 8 ; 12]$ і визначенню об'єктивних чинників порушення процесу політико-правової соціалізації громадян сучасної України (В. М. Духневич, 2015; О. М. Скнар, 2017; Т. М. Титаренко, 2017) $[3 ; 10 ; 11]$.

Невирішені частини загальної проблеми. Напрацьований у ході цих досліджень матеріал дає підстави для того, аби констатувати, що особистісна ідентичність являє собою динамічне системне утворення, що постійно перебуває в розвитку. У процесі соціалізації (результатом якої і $є$ самовизначення особистості щодо тих чи інших сфер життя) людина не тільки піддається впливу певних агентів соціалізації, а й сама стає суб'єктом вибору, інтерпретації та перетворення змісту цих впливів у свою власну концепцію дійсності. Цим і пояснюється те, що за однакових обставин життя або під час взаємодії з одними й тими ж самими агентами соціалізації люди по-різному долають кризи ідентичності та формують діаметрально протилежні ставлення до суспільно значущих подій та явищ. Вивчення цієї суб'єктивної складової процесу політико-правового самовизначення особистості досі ще не проводилось. Утім, 3'ясувати ці питання необхідно не тільки для оптимізації процесу громадянської соціалізації сучасних українців, а i їхньої здатності долати життєві кризи без втрат для свого біопсихосоціального здоров'я.

Мета статті полягає у створенні теоретичних засад вивчення та оптимізації тих суб'єктивних стратегій, до яких вдається особистість у ході вирішення завдань політико-правової ідентифікації, що враховує актуальність та недостатню вивченість проблем конструювання особистістю політико-правової дійсності в умовах гібридної (i зокрема інформаційної) війни. Об'єкт дослідження: процес вибору особистістю своїх способів ставлення до суперечливих варіантів розуміння та оцінювання політико-правової дійсності. Предмет дослідження: актуалізація стану ідентичності як прояв суб'єктивних стратегій особистості, спрямованих на долання невизначеності комунікативної ситуації.

Виклад основного матеріалу дослідження. Процес політичної соціалізації наука тривалий час розглядала як вплив політичного середовища на особистість, коли певні моделі мислення і поведінки передаються через систему організованих громадських інститутів i цінностей. При цьому індивіди або групи розглядалися як пасивні об'єкти соціалізації, а сам процес соціалізації - як “вертикальні” відносини між тими, хто соціалізує, і тими, кого соціалізують. Результатом соціалізації стає розвиток особистісної ідентичності - системи суб'єк- 
тивних конструкцій дійсності, що зумовлюють самовизначення людини щодо тих чи інших сфер дійсності. У процесі соціалізації людина так чи інакше переживає кризи ідентичності, пов'язані 3 необхідністю самовизначення щодо способів взаємодії із соціумом, який змінює свої вимоги до неї. Ці вимоги в умовах традиційного суспільства були більш-менш стабільні, тож проходження криз ідентичності переважно корелювало з віком його членів, які в міру дорослішання мали засвоювати нові суспільні норми, цінності, ролі тощо.

Сучасна епоха швидких змін у соціокультурній системі відрізняється від стабільного суспільства тим, що глобальні трансформації вкладаються в проміжки часу, менші за період життя людини. Це створює умови для “масових" криз ідентичності, які корелюють не з віком людини, а зі змінами в суспільному житті. Якщо суспільство різко змінює вимоги до своїх членів, то громадяни не завжди встигають відповідним чином відкоригувати свої суб'єктивні конструкції дійсності й знайти свої способи життєздійснення в нових умовах. Процеси модернізації, інформатизації, глобалізації суспільства, які визначають новий спосіб соціального життя з кінця ХХ століття, відбиваються і на процесі соціалізації громадян.

Наукові дослідження специфіки процесу соціалізації особистості в епоху глобалізації світу виявили такі феномени, як зниження ролі авторитету віку - більш старший вік батьків, учителів, наприклад, не стає підставою для поваги і наслідування; те ж саме відбувається і в контексті родинних стосунків - роль родинних зв'язків знижується. Крім того, у сучасному світі процес соціалізації втратив свою односторонню спрямованість: політичні цінності та переконання тепер транслюються не тільки в “один бік” - від старшого покоління до молодшого, а й у другий - $є$ чимало даних, що молоді люди ретранслюють свої власні політичні орієнтації батькам [4; 14].

Теоретичне усвідомлення тих змін, що відбулися в соціальній та політичній реальності, утілилося в моделі переходу від “вертикальної” до “горизонтальної” соціалізації особистості. Цю модель запропонував 1986 р. Р. Мерелман [14] як принципово нове розуміння механізму засвоєння і ретрансляції політичних цінностей і настановлень у період модернізації суспільства. Згідно з його ідеєю “горизонтальної (lateral) політичної соціалізації цей процес $є$ безперервним вибором із широкого числа можливих і конкуруючих між собою образів світу і моделей поведінки, кількість яких постійно збільшується в результаті взаємин між "рівними" учасниками процесу соціалізації на "горизонтальному" рівні. У “горизонтальній” соціалізації відносини між об’єктом і агентами соціалізації добровільні, рівні і тимчасові. Особистість того, хто соціалізується, стає центром моделі, на відміну від моделі “вертикальної” соціалізації, де особистість виявлялася своєрідним “кінцем” ланцюжка впливів. 
Розведення цих двох моделей політико-правової соціалізації не означає, що вони протистоять одна одній. Їх можна розглядати і як такі, що взаємно доповнюють одна одну, різною мірою сприяють соціалізації на різних етапах розвитку особистості. Так, Ф. Васбурн пропонує таку модель процесу політичної соціалізації: стадії життєвого циклу особи (дитинство, підлітковий вік, юність, зрілість і старість) і агенти соціалізації (сім'я, в якій особа виховувалася, школа, церква, ЗМI, родина самої особи, іiї робота і політичний досвід) являють собою інтерактивні системи. Між агентами соціалізації існують комплексні взаємини на всіх стадіях життєвого циклу, і відносна значущість кожного агента соціалізації може варіювати від одного періоду життєвого циклу до іншого. Політичні орієнтації особи в будь-якій точці життевого циклу визначаються як об'єктивними умовами ії життя (до яких можна віднести й інформаційні впливи агентів соціалізації), так i суб'єктивними способами конструювання цієї дійсності (стратегіями ідентифікації).

Іншими словами, результат соціалізації (особистісна ідентичність) залежить не тільки від позицій різних агентів соціалізації, а й від того, як особистість робить вибір між різними варіантами осмислення дійсності: як сприймає, переживає й опрацьовує пропоновані їй варіанти. Якщо в традиційному суспільстві (за “вертикальної” моделі соціалізації) іiі бажаним результатом ще можна було вважати “запозичену політикоправову ідентичність” (засвоєння особою тих цінностей та настановлень, що панують у соціумі), то в період глобальних змін суспільного устрою це вже неможливо. По-перше, тому що такої однодумності в суспільстві вже не існує, а по-друге, тому що соціокультурні трансформації відбуваються швидше, ніж зміна поколінь. Тому відповіддю на виклик часу стає необхідність розвитку суб'єктної позиції особистості в розбудові власної ідентичності - іiі здатності свідомо формувати свій образ політико-правової дійсності на основі виявлення і засвоєння суперечностей між наявними в соціумі точками зору.

Актуальність завдань розвитку суб'єктної позиції особистості в конструюванні власного образу політико-правової дійсності вимагає від психологічної науки вивчення проявів цієї позиції в суб'єктивних способах смислоутворення (в індивідуальних стратегіях прийняття рішення щодо того, що сприймати, як це інтерпретувати і як із цим бути) [6]. Оскільки особистість завжди є суб'єктом вибору свого способу ставлення до виявлених невизначеностей комунікативної ситуації, ці вибрані нею контекстуальні способи смислоутворення відрізняються мірою їх спрямованості на збереження/розвиток власних конструкцій дійсності. Якщо ці інтенції до стабілізації і вдосконалення своїх моделей дійсності реалізуються повною мірою, то особистість виступає в цій комунікативній ситуації “суб'єктом саморозвитку”. У разі обме- 
женої реалізації однієї із цих інтенцій, або їх обох, особистість блокує контакт зі своїм смислотворчим потенціалом і втрачає можливості його розвитку. Можна сказати, що в таких комунікативних ситуаціях особистість стає “суб'єктом самообмеження”. Прояв тієї чи іншої “суб'єктної позиції” особистості залежить від контексту комунікативної ситуації (констеляції обставин у їх даності суб’єкту комунікації).

Самообмеження особистості в процесі смислоутворення (створення смислової основи вибору свого способу ставлення до невизначеності комунікативної ситуації) проявляються у блокуванні наявних можливостей сприймати, досліджувати та солідаризувати альтернативні варіанти вибору. Ці самообмеження проявляються, відповідно, у тому, що процес ідентифікації припиняється, дестабілізується або тимчасово гальмується. Повноцінність процесу смислоутворення (“завершеність циклу контакту з актуалізованими смисловими суперечностями") [1] проявляється в здійсненні таких суб'єктивних виборів, що сприяють “досяганню особистісної ідентичності” (iї зміні без втрати стабільності).

Теорія статусів ідентичності, розроблена Дж. Марсіа [13], дає змогу досліджувати не тільки зміст та структуру набутих особистістю моделей самовизначення, а й динамічні характеристики процесу іiі ідентифікації. Такий “процесуальний” підхід до вивчення проблем самовизначення особистості стає все більш популярним у сучасній науці (Дж. Р. Адамс, 1979; А. Ватерман, 1985; В. Турячанін, Д. Майсторович, 2013; А. ван Доммелен, К. Шмід, М. Х'юстон, К. Гонсалкорале, М. Брюер, 2015), оскільки пропонує процедуру визначення тих способів ідентифікації, що визначають повноцінність або обмеженість актуалізованого “статусу ідентичності”.

Статуси ідентичності визначаються за параметром суб'єктивно прийнятих засобів розв'язання особистістю смислотворчих проблем: “прийняття чи уникання зобов'язань" (commitment) та “дослідження або витіснення альтернатив" (exploration of alternatives). Перший параметр відображає прояв особистісної інтенції до самоздійснення (до реалізації суб'єктивних моделей дійсності в процесі конструювання виборів); другий - прояв іiі інтенції до саморозвитку (до засвоєння розвивальних ресурсів виявлених смислових суперечностей).

Якщо в процесі смислоутворення особистість реалізує обидві інтенції, то іiї вибори актуалізують статус "досягання ідентичності" (identity achievement). Статус "запозиченої ідентичності” (foreclosure identity) актуалізується тоді, коли особистість обмежує реалізацію обох інтенцій - не виробляє власної позиції, а приєднується до думки референтної групи і намагається захистити такі ззовні накинуті переконання від змін. Два інших типи статусів ідентичності $є$ проявом порушення балансу в реалізації тих самих інтенцій: статус “дифузної ідентичності" (identity diffusion) спричиняється особистісними обмеженнями само- 
здійснення, а “мораторій ідентичності" (moratorium) - обмеженнями саморозвитку.

Критеріями “неприйняття зобов'язань” є виявлені в ході інтерв'ю прояви делегування цих обов'язків іншим людям чи групам, стереотипізація відповідних моделей дійсності, неможливість побачити їхні внутрішні суперечності, недостатня усвідомленість підстав своїх виборів тощо. Критеріями “неопрацювання альтернатив” $є$ прояви амбівалентності в ставленнях людини до відповідної сфери життя, наявність великої кількості нерозв'язаних смислових суперечностей, відстрочування здійснення вибору через страх схибити. Тобто, як очевидно, обидва параметри, на перетині яких Дж. Марсіа виділяє статуси ідентичності, розкривають способи, якими особистість обмежує реалізацію свого смислотворчого потенціалу в процесі конструювання життєвих виборів.

Теоретичний аналіз проблеми політико-правової ідентифікації особистості з позицій повноцінності/обмеженості смислотворчої комунікації суб'єкта вибору із суперечливими варіантами конструювання дійсності дає змогу, по-перше, розкрити психологічну природу актуалізації тих чи інших статусів ідентичності; а по-друге - розробити соціальні технології розвитку суб'єктної позиції особистості в процесі вирішення питань політико-правового плану. 3 огляду на комунікативну природу та контекстуальну зумовленість процесу смислоутворення актуалізація статусу “досягання ідентичності” потребує залучення особи до таких контекстів взаємодії, в яких іiі повноцінне самоздійснення і саморозвиток стають необхідними і можливими. Це можуть бути різноманітні соціальні практики (дотичні певним чином до політико-правової сфери життя), в яких бажаний для всіх результат може бути досягнутий лише шляхом виявлення, вивчення та засвоєння тих суперечностей, що виникають між носіями різних поглядів на дійсність.

Отже, проведене нами теоретичне дослідження проблеми вибору особистістю способів політико-правового самовизначення особистості в епоху соціальних потрясінь дає підстави зробити такі висновки:

1. В умовах політичної нестабільності і в ситуації "гібридної війни”, що триває в сучасній Україні, процес політико-правової ідентифікації громадян залежить не так від інформаційних впливів агентів соціалізації (що воюють за уми), як від того, яким чином особистість здійснює вибір між суперечливими варіантами осмислення дійсності.

2. Процес здійснення особистісних виборів являє собою смислотворчу комунікацію, в якій особистість може як обмежувати свої інтенції до самоздійснення й саморозвитку, так і повною мірою їх реалізувати. Повноцінність процесу смислотворчої комунікації проявляється в тому, що виявлені в ході конструювання вибору смислові суперечності усвідомлюються, досліджуються і засвоюються суб'єктом комунікації. 
3. Залежно від типу самообмежень особистості, які порушують стабілізацію або змінюваність набутої моделі ідентичності, можна виділити чотири основні стратегії взаємодії суб'єкта вибору із суперечливими варіантами конструювання дійсності. Такими стратегіями є: збалансована реалізація інтенцій до самоздійснення та до саморозвитку; обопільне обмеження цих інтенцій; обмеження переважно інтенції до самоздійснення або інтенції до саморозвитку.

4. Кожна із цих стратегій проявляється в актуалізації відповідного статусу процесу ідентифікації: оптимального “досягання ідентичності" та проблемних - "запозиченої ідентичності”, “дифузної ідентичності” та "iї мораторію”. Це дає змогу скористатися процедурою "напівструктурованого інтерв’ю статусів ідентичності” Дж. Марсіа як методом вивчення способів політико-правового самовизначення особистості. Ідеться про те, що діагностичний параметр “стійкості суб'єктивних конструктів і прийняття зобов'язань” відображає міру реалізації в здійснюваних досліджуваним виборах особистісної інтенції до самоздійснення, а параметр “опанування кризи, опрацювання альтернатив" міру реалізації інтенції до саморозвитку.

5. Оскільки процес смислотворчості має комунікативну природу і залежить від контексту взаємодії, в якій відбувається самовизначення особистості щодо певної (у тому числі і політико-правової) сфери дійсності, можна припустити, що чинником прийняття особистістю тієї чи іншої стратегії політико-правового самовизначення є якість особистого досвіду взаємодії з оточенням у процесі вирішення відповідних питань.

Перспективи подальших досліджень полягають у тому, щоб емпірично перевірити висунуте припущення про вплив способів організації взаємодії з агентами соціалізації на повноцінність/обмеженість самореалізації особистості в процесі розв'язання проблем політикоправової ідентифікації.

\section{Лimepamypa}

1. Гингер С. Гештальт-терапия контакта / С. Гингер, А. Гингер ; пер. с фр. Е. В. Просветиной. - Санкт-Петербург : Специальная литература, 1999. $287 \mathrm{c}$.

2. Горностай П. П. Громадянська ідентичність українців та ії еволюція / П. П. Горностай // Проблеми політичної психології : зб. наук. праць / Асоц. політ. психологів України, Ін-т соц. та політ. психології НАПН України. - Київ : Міленіум, 2015. - Вип. 2 (16). - С. 98-111.

3. Духневич В. М. Особливості політико-правової активності молоді в умовах трансформації українського суспільства / В. М. Духневич // Юридична психологія. - 2016. - № 1 (18). - С. 33-45.

4. Ильясов Ф. Н. Политическая социализация / Ф. Н. Ильясов // Политический маркетинг. Искусство и наука побеждать на выборах. - Москва : ИМА-пресс, 2000. - C. 32-38. 
5. Кравчук С. Л. До проблеми дослідження духовних цінностей та неконструктивних форм поведінки молоді у політико-правовій сфері в умовах воєнного конфлікту / С. Л. Кравчук // Науковий часопис Національного педагогічного університету імені М. П. Драгоманова. Психологічні науки : зб. наук. праць. - Київ : НПУ імені М. П. Драгоманова, 2017. № 6 (51). - С. 182-190.

6. Осадько О. Ю. Общение как эликсир здоровья (Коммуникативные механизмы саногенеза личности) : монография / О. Ю. Осадько. - Киев : Миллениум, 2016. - 340 с.

7. Остапенко I. B. Концептуальні засади дослідження комунікативних бар'єрів національної та громадянської ідентифікації / І. В. Остапенко // Український психологічний журнал. - 2016. - № 2. - С. 73-84.

8. Семенова Ю. А. Криза ідентичності в умовах трансформації системи цінностей / Ю. А. Семенова // Гуманітарний часопис. - 2004. - № 1. C. 96-103.

9. Сіверс 3. Ф. Уявлення молоді про власні права як показник очікувань інституціональної справедливості / 3. Ф. Сіверс // Наукові студії із соціальної та політичної психології : зб. статей / Нац. акад. пед. наук України, Ін-т соц. та політ. психології. - Київ : Міленіум, 2015. Вип. 35 (38). - С. 175-185.

10. Скнар О. М. Модель емпіричного дослідження комунікативних практик розвитку самосвідомості як чинника громадянської та національної самоідентифікації молоді / О. М. Скнар // Проблеми політичної психології : зб. наук. праць / Асоц. політ. психологів України, Ін-т соц. та політ. психології НАПН України. - Київ : Міленіум, 2017. - № 5 (19) - С. 179-187.

11. Титаренко Т. М. Особистість перед викликами війни: психологічні наслідки травматизації / Т. М. Титаренко // Проблеми політичної психології : зб. наук. праць / Асоц. політ. психологів України, Ін-т соц. та політ. психології НАПН України. - Київ : Міленіум, 2017. - Вип. 5 (19). - С. 3-11.

12. Шевченко 3. В. Криза ідентичності як деструктивний прояв індивідуалізму: соціально-філософський аналіз / З. Ф. Шевченко // Вісник Черкаського університету. Серія: Філософія. - Черкаси, 2007. - Вип. 106. C. 37-46.

13. Marcia J. E. Identity in adolescence [Electronic resourse] / J. E. Marcia ; J. Adelson (ed.) // Handbook of adolescent psychology. - New York : John Wiley, 1980. - P. 159-187. - Access mode : https://www.researchgate.net/profile/ James_Marcia/publication/233896997_Identity_in_adolescence.

14. Merelman R. M. Revitalizing Political Socialization / R. M. Merelman ; M. Hermann (ed.) // Political Pshychology. - San-Francisco, 1986. - P. 279-319.

15. Wasburn Ph. A life Course Model of Political Socialization / Ph. Wasburn // Politics and Individual. - 1994. - Vol. 4. - №2. - P. 1-26.

\section{References}

1. Ginger, S. \& Ginger, A. (1999). Geshtalt-terapiya kontakta [Gestalt-contact therapy]. St. Petersburg: Spetsialnaya literatura Publ. (rus).

2. Gornostay, P. P. (2015). Hromadianska identychnist ukraintsiv i yii evoliutsiia [Civic identity of Ukrainians and their evolution]. Problemy politychnoi psykholohii [Problems of Political Psychology], 2 (16), 98-111 (ukr) . 
3. Dukhnevych, V. M. (2016). Osoblyvosti polityko-pravovoi aktyvnosti molodi v umovakh transformatsii ukrainskoho suspilstva [Features of political and legal activity of youth in the conditions of transformation of Ukrainian society]. Yurydychna psykholohiia [Legal Psychology], 1 (18), 33-45 (ukr).

4. Ilyasov, F. N. (2000). Politicheskaya sotsializatsiya [Political socialization]. In F. N. Ilyasov, Politicheskiy marketing. Iskusstvo i nauka pobezhdat na vyborakh [Political marketing. Art and science nin elections]. Moscow: IMA-press Publ., pp. 32-38 (rus).

5. Kravchuk, S. L. (2017). Do problemy doslidzhennia dukhovnykh tsinnostei ta nekonstruktyvykh form povedinky molodi u polityko-pravovii sferi v umovakh voiennoho konfliktu [To the problem of the study of spiritual values and nonconstructive forms of youth behavior in the political and legal sphere in the context of a military conflict]. Naukovyi chasopys Natsionalnoho pedahohichnoho universytetu imeni M.P. Drahomanova. Psykholohichni nauky [Scientific Bulletin of the National Pedagogical University named after M. P. Dragomanov. Psychological sciences], 6 (51), 182-190 (ukr).

6. Osadko, O. Yu. (2016). Obshcheniye kak eliksir zdorovya (Kommunikativnyye mekhanizmy sanogeneza lichnosti) [Communication as an Elixir of Health (Communicative mechanisms of the personality sanogenesis)]. Kyiv: Millenium Publ. (rus).

7. Ostapenko, I. V. (2016). Kontseptualni zasady doslidzhennia komunikatyvnykh barieriv natsionalnoi i hromadianskoi identyfikatsii [Conceptual framework for studying the communication barriers of national and civic identification]. Ukrainskyi psykholohichnyi zhurnal [Ukrainian Psychological Journal], 2, 73-84.

8. Semenova, Yu. A. (2004). Kryza identychnosti v umovakh transformatsii systemy tsinnostei [Identity crisis in the context of the transformation of the value system]. Humanitarnyi chasopys [Gumanitarian Newsletter], 1, 96-103 (ukr).

9. Sivers, Z. F. (2015). Uiavlennia molodi pro vlasni prava yak pokaznyk ochikuvan instytutsionalnoi spravedlyvosti [Representation of young people about their rights as an indicator of the expectations of institutional justice]. Naukovi studii iz sotsialnoi ta politychnoi psykholohii [Scientific Studies in Social and Political Psychology], 35 (38), 175-185 (ukr).

10. Sknar, O. M. (2017). Model empirychnoho doslidzhennia komunikatyvnykh praktyk rozvytku samosvidomosti yak chynnyka hromadianskoi i natsionalnoi samoidentyfikatsii molodi [Model of empirical research of communicative practices of the development of self-awareness as a factor in the civic and national identity of young people]. Problemy politychnoi psykholohii [Problems of Political Psychology], 5 (19), 179-187 (ukr).

11. Tytarenko, T. M. (2017). Osobystist pered vyklykamy viiny: psykholohichni naslidky travmatyzatsii [Personality before the challenges of war: the psychological consequences of traumatism]. Problemy politychnoi psykholohii [Problems of Political Psychology], 5 (19), P. 3-11 (ukr).

12. Shevchenko, Z. V. (2007). Kryza identychnosti yak destruktyvnyi proiav indyvidualizmu: sotsialno-fílosofskyi analiz [Identity crisis as destructive manifestation of individualism: socio-philosophical analysis]. Visnyk Cherkaskoho universytetu. Seriia: Filosofiia [Bulletin of the University. Series: Philosophy], 106, 37-46 (ukr). 
13. Marcia, J. E. (1980). Identity in adolescence. In Adelson J. (ed.), Handbook of adolescent psychology. New York: John Wiley, pp. 159-187, https://www.researchgate.net/profile/James Marcia.

14. Merelman, R. M. (1986). Revitalizing Political Socialization. In Hermann M. (ed.), Political Pshychology. San-Francisco, pp. 279-319.

15. Wasburn, Ph. (1994). A life Course Model of Political Socialization. Politics and Individual, vol. 4, no. 2, pp. 1-26.

Osadko O. Yu. The Problem of Personality's Choice of The Ways of Political-and-Legal Self- Determination in the Situation of Social Upheavals

The article is dedicated to the creation of theoretical foundations for the study and optimization of those subjective strategies to which the person uses while solving the problems of political and legal identification. The author defends the notion that during the period of social upheavals in Ukraine, the result of social ization (in particular, acquisition of political and legal identity) depends not only on the competing influences of various agents of socialization but on how the person chooses between different ways of comprehension of reality. The necessity of the studying of the subjective ways of implementing identity elections, and not only studying the content and structure of the identities acquired by it, is emphasized. The article notes that J. Marsia's conception of the identity status is aimed at revealing the ways with the help of which the subject of socialization creates the semantic basis of their identification choices. It is shown that the type of individual's selflimitation, which violates the stabilization or modification of the acquired model of identity, gives an opportunity to highlight four basic strategies of an interaction of the subject of choice with different variants of constructing reality. Such strategies are: balanced implementation of intentions of self-realization and self-development ("identity achievement"); the mutual restriction of these intentions ("foreclosure identity"); mainly the restriction of the intention of self-realization ("identity diffusion") or, preferably, the intention of self-development ("moratorium on identity"). The author concludes that the involvement of the subject of socialization in communicative practices, where his semantic self-limitations will be removed contributes to overcoming of identity crises.

Key words: models of individual's socialization, personality's self-limitations, self-realization, self-development, cognitive communication, strategies of politicaland-legal self-determination, identity status.

(C) Осадько О. Ю. 